\title{
Microbulbifer maritimus sp. nov., isolated from an intertidal sediment from the Yellow Sea, Korea
}

Correspondence

Jung-Hoon Yoon

jhyoon@kribb.re.kr
The genus Microbulbifer was proposed by González et al. (1997) for a novel rod-shaped and strictly aerobic marine bacterium that belonged to the Proteobacteria. A single species, Microbulbifer hydrolyticus, was included within this genus. The second species of the genus Microbulbifer was Microbulbifer salipaludis, which was proposed recently by Yoon et al. (2003b). Phylogenetic analyses based on $16 \mathrm{~S}$ rDNA sequences have shown that the two Microbulbifer species fall within the $\gamma$-subclass of the Proteobacteria (González et al., 1997; Solano \& Sanchez-Amat, 1999; Anzai et al., 2000; Yoon et al., 2003b). Chemical markers of this genus include the presence of a major amount of iso- $\mathrm{C}_{15: 0}$ and ubiquinone with eight isoprene units (Q-8) (González et al., 1997; Yoon et al., 2003b). The DNA G+C content of the genus is $58-59 \mathrm{~mol} \%$ (González et al., 1997; Yoon et al., 2003b). Pigmentation of the colonies of these two Microbulbifer species is cream or greyish-yellow. Recently, Pseudomonas elongata was transferred to the genus Microbulbifer as Microbulbifer elongatus (Yoon et al.,

Published online ahead of print on 23 January 2004 as DOI 10.1099/ ijs.0.02985-0.

Abbreviation: TEM, transmission electron microscopy.

The GenBank/EMBL/DDBJ accession number for the 16S rDNA sequence of strain TF-17 $17^{\top}$ is AY377986. 2003a). The colour of M. elongatus was yellowish-brown, unlike the first two Microbulbifer species that were described. In the course of screening taxonomically useful micro-organisms that were present in an intertidal sediment from the Yellow Sea (Korea), a yellowish browncoloured, slightly halophilic bacterial strain $\left(\mathrm{TF}-17^{\mathrm{T}}\right)$ was isolated and characterized taxonomically. The result of $16 \mathrm{~S}$ rDNA sequence comparison indicated that this isolate is related phylogenetically to members of the genus Microbulbifer. Accordingly, the aim of this work was to establish the exact taxonomic position of strain TF- $17^{\mathrm{T}}$ by polyphasic characterization, which included phenotypic properties, detailed phylogenetic analysis based on $16 \mathrm{~S}$ rDNA sequences and genomic relatedness.

Strain TF- $17^{\mathrm{T}}$ was isolated by the dilution-plating technique on marine agar 2216 (MA; Difco). Cell biomass of strain $\mathrm{TF}-17^{\mathrm{T}}$ for respiratory lipoquinone analysis and for DNA extraction was obtained from cultures in marine broth 2216 (MB; Difco) at $37^{\circ} \mathrm{C}$. For fatty acid methyl ester analysis, cell mass of strain TF- $17^{\mathrm{T}}$ was obtained from agar plates after incubation for 3 days at $37^{\circ} \mathrm{C}$ on MA. Cell morphology was examined by light microscopy and transmission electron microscopy (TEM). Flagellum type was examined by TEM using cells from an exponentially growing culture. Gram-reaction was determined by using a Gram Stain kit 
(bioMérieux) according to the manufacturer's instructions. Growth under anaerobic conditions was determined after incubation in an anaerobic chamber with anaerobically prepared MA. Growth in the absence of $\mathrm{NaCl}$ was investigated in trypticase soy broth to which $\mathrm{NaCl}$ was not added. Growth at various $\mathrm{NaCl}$ concentrations $(0 \cdot 5-15 \%)$ was investigated in $\mathrm{MB}$ or in trypticase soy broth. Growth at various temperatures $\left(4-55^{\circ} \mathrm{C}\right)$ was measured on MA. Catalase activity was determined by bubble production in $3 \%(\mathrm{v} / \mathrm{v}) \mathrm{H}_{2} \mathrm{O}_{2}$ solution. Oxidase activity was determined by oxidation of $1 \% p$-aminodimethylaniline oxalate. Hydrolysis of gelatin and aesculin and nitrate reduction were determined as described by Lanyi (1987), with the modification that artificial sea water was used. Artificial sea water contained [(l distilled water $)^{-1}$ ]: $23.6 \mathrm{~g} \mathrm{NaCl}$; $0.64 \mathrm{~g} \mathrm{KCl} ; 4.53 \mathrm{~g} \mathrm{MgCl}_{2} .6 \mathrm{H}_{2} \mathrm{O} ; 5.94 \mathrm{~g} \mathrm{MgSO}_{4} .7 \mathrm{H}_{2} \mathrm{O}$; $1.3 \mathrm{~g} \mathrm{CaCl}_{2} \cdot 2 \mathrm{H}_{2} \mathrm{O}$ (Levring, 1946). Hydrolysis of casein and starch was determined as described by Cowan \& Steel (1965). Hydrolysis of hypoxanthine, tyrosine, xanthine and Tween 80 was tested on MA plates by using substrate concentrations that were described by Cowan \& Steel (1965). Hydrolysis of chitin (Sigma) and birchwood xylan (Sigma) was determined on solid and in liquid marine salts basal medium (Baumann \& Baumann, 1981) that contained $0.5 \%$ chitin or xylan as the sole carbon source, respectively. M. hydrolyticus DSM $11525^{\mathrm{T}}$ was used as positive control for hydrolysis tests of chitin and xylan. Additional enzyme activity was determined by using the API ZYM system (bioMérieux). Acid production from carbohydrates was determined as described by Leifson (1963). Utilization of various substrates for growth was determined as described by Yurkov et al. (1994).

Chromosomal DNA was isolated and purified according to a method described previously (Yoon et al., 1996), except that ribonuclease $\mathrm{T} 1$ was used together with ribonuclease A. Respiratory lipoquinones were analysed as described by Komagata \& Suzuki (1987), using reversed-phase HPLC. For quantitative analysis of cellular fatty acid compositions, a loop of cell mass was harvested and fatty acid methyl esters were prepared and identified by following the instructions of the Microbial Identification system (MIDI). DNA G + C content was determined by the method of Tamaoka \& Komagata (1984). DNA was hydrolysed and the resultant nucleotides were analysed by reversed-phase HPLC.

16S rDNA was amplified by PCR using two universal primers (Yoon et al., 1998). The PCR product was purified with a QIAquick PCR purification kit (Qiagen). Sequencing of the purified $16 \mathrm{~S}$ rDNA was performed by using an $\mathrm{ABI}$ PRISM BigDye Terminator cycle sequencing ready reaction kit (Applied Biosystems) as recommended by the manufacturer. The purified sequencing reaction mixtures were electrophoresed automatically on an Applied Biosystems model 377 automatic DNA sequencer. Alignment of sequences was carried out with CLUSTAL $\mathrm{W}$ software (Thompson et al., 1994). Gaps at the 5' and 3' ends of the alignment were omitted from further analysis. Phylogenetic trees were inferred by using three tree-making algorithms: the neighbour-joining (Saitou \& Nei, 1987), maximumlikelihood (Felsenstein, 1981) and maximum-parsimony (Kluge \& Farris, 1969) methods, implemented within the PHYLIP package (Felsenstein, 1993). Evolutionary distance matrices for the neighbour-joining method were calculated according to Jukes \& Cantor (1969) by using the program DNADIST in the PHYLIP package. Stability of relationships was assessed by a bootstrap analysis based on 1000 resamplings of the neighbour-joining dataset, using the programs SEQBOOT, DNADIST, NEIGHBOR and CONSENSE of the PHYLIP package. DNA-DNA hybridization was performed fluorometrically by the method of Ezaki et al. (1989), using photobiotin-labelled DNA probes and microdilution wells. Hybridization was performed with five replications for each sample; the highest and lowest values obtained for each sample were excluded and the remaining three values were used to calculate similarity values. DNADNA relatedness values quoted are the means of these three values.

Cells of strain TF- $17^{\mathrm{T}}$ were rods that measured approximately $0 \cdot 3-0 \cdot 5 \mu \mathrm{m}$ in width and $3 \cdot 0-6 \cdot 0 \mu \mathrm{m}$ in length after cultivation for 3 days at $37^{\circ} \mathrm{C}$ on MA. Strain TF- $17^{\mathrm{T}}$ had no flagella. Colonies on MA were yellowish-brown in colour, smooth, irregular, slightly raised and $2 \cdot 0-4 \cdot 0 \mathrm{~mm}$ in diameter after 3 days incubation at $37^{\circ} \mathrm{C}$ on MA. Strain TF- $17^{\mathrm{T}}$ grew optimally at $37^{\circ} \mathrm{C}, \mathrm{pH} 6 \cdot 5-7 \cdot 5$ and in the presence of $2-4 \%(\mathrm{w} / \mathrm{v}) \mathrm{NaCl}$. Strain $\mathrm{TF}-17^{\mathrm{T}}$ did not grow under anaerobic conditions on MA. Phenotypic properties of strain TF- $17^{\mathrm{T}}$ are shown in Table 1 or are given in the species description (see below). As shown in Table 1, there are differences between TF- $17^{\mathrm{T}}$ and the other Microbulbifer species in some phenotypic characteristics.

The predominant respiratory lipoquinone found in strain $\mathrm{TF}-17^{\mathrm{T}}$ was unsaturated ubiquinone with eight isoprene units (Q-8), at a peak area ratio of approximately $95 \%$. Strain $\mathrm{TF}-17^{\mathrm{T}}$ had a cellular fatty acid profile that contained major amounts of straight-chain, branched and hydroxy fatty acids; it contained iso- $\mathrm{C}_{15: 0}$ as the major fatty acid and also significant amounts of iso- $\mathrm{C}_{11: 0} 3-\mathrm{OH}$ and iso$\mathrm{C}_{17: 1} \omega 9 c$ (Table 2). This profile was similar to those of the type strains of $M$. hydrolyticus, $M$. salipaludis and $M$. elongatus, although there are differences in the proportions of some fatty acids, such as iso- $\mathrm{C}_{11: 0}$, iso- $\mathrm{C}_{11: 0}$ $3-\mathrm{OH}$ and $\mathrm{C}_{18: 1} \omega 7 c$. The DNA G+C content of strain $\mathrm{TF}-17^{\mathrm{T}}$ was $59 \cdot 9 \mathrm{~mol} \%$.

An almost-complete 16S rDNA sequence of $1490 \mathrm{nt}$ (approximately $96 \%$ of the Escherichia coli $16 \mathrm{~S}$ rRNA gene sequence) was determined for strain TF- $17^{\mathrm{T}}$. Strain $\mathrm{TF}-17^{\mathrm{T}}$ was found to have highest $16 \mathrm{~S}$ rDNA sequence similarity to members of the $\gamma$-subclass of the Proteobacteria and, in particular, to the genus Microbulbifer. In the phylogenetic tree based on the neighbour-joining algorithm, strain TF- $17^{\mathrm{T}}$ clustered with the type strains of M. hydrolyticus, M. salipaludis and M. elongatus (Fig. 1). The 
Table 1. Differential phenotypic characteristics of strain $\mathrm{TF}-17^{\top}, M$. hydrolyticus, M. salipaludis and $M$. elongatus

Taxa: 1, strain TF-17 $17^{\mathrm{T}}$; 2, M. hydrolyticus [data from González et al. (1997)]; 3, M. salipaludis [data from Yoon et al. (2003b)]; 4, M. elongatus [data from Humm (1946), Palleroni (1984) and Yoon et al. (2003a)]. +, Positive reaction; -, negative reaction; W, weakly positive reaction; ND, not determined. All species were positive for hydrolysis of starch, catalase and acid production from D-cellobiose and maltose. All species were negative for spore formation, Gram-staining, acid production from D-fructose, D-galactose, lactose and D-mannose and growth at $0 \% \mathrm{NaCl}$.

\begin{tabular}{|c|c|c|c|c|}
\hline Characteristic & 1 & 2 & 3 & 4 \\
\hline Cell morphology & Rods & Rods & Rods & Cocci or rods \\
\hline Colour of colonies & Yellowish-brown & Cream & Greyish-yellow & Yellowish-brown \\
\hline Motility & - & - & - & + \\
\hline Oxidase & + & + & + & $\mathrm{ND}$ \\
\hline Nitrate reduction to nitrite & - & $\mathrm{ND}$ & ND & - \\
\hline \multicolumn{5}{|l|}{ Hydrolysis of: } \\
\hline Aesculin & - & + & - & $\mathrm{ND}$ \\
\hline Agar & - & - & $\mathrm{w}+$ & + \\
\hline Casein & + & + & $\mathrm{w}+$ & $\mathrm{ND}$ \\
\hline Chitin & - & + & - & + \\
\hline Gelatin & + & + & ND & + \\
\hline Tween 80 & + & + & + & ND \\
\hline$N$-Acetyl- $\beta$-glucosaminidase & - & - & + & + (this study) \\
\hline \multicolumn{5}{|l|}{ Acid production from: } \\
\hline L-Arabinose & - & + & - & + \\
\hline D-Glucose & - & + & + & - \\
\hline Sucrose & - & - & - & + \\
\hline D-Trehalose & + & - & - & $\mathrm{ND}$ \\
\hline D-Xylose & - & + & - & + \\
\hline Growth at $\mathrm{pH} 6 \cdot 0$ & + & - & + & $\mathrm{ND}$ \\
\hline Growth at $10 \% \mathrm{NaCl}$ & + & - & + & $\mathrm{ND}$ \\
\hline \multicolumn{5}{|l|}{ Growth temperature $\left({ }^{\circ} \mathrm{C}\right)$ : } \\
\hline Maximum & 48 & 41 & 45 & ND \\
\hline Optimum & 37 & 37 & 37 & $25-30$ \\
\hline DNA G $+\mathrm{C}$ content $(\mathrm{mol} \%)$ & $59 \cdot 9$ & 58 & 59 & ND \\
\hline
\end{tabular}

relationship between strain $\mathrm{TF}-17^{\mathrm{T}}$ and the clade comprising the type strains of the three Microbulbifer species was supported by bootstrap analysis at a confidence level of $100 \%$. Similar tree topologies were generated by the maximum-parsimony method (data not shown). Strain TF- $17^{\mathrm{T}}$ showed $16 \mathrm{~S}$ rDNA sequence similarity levels of $95 \cdot 1,95 \cdot 7$ and $95 \cdot 3 \%$ to M. hydrolyticus ATCC $700072^{\mathrm{T}}$, M. salipaludis KCCM $41586^{\mathrm{T}}$ and M. elongatus DSM $6810^{\mathrm{T}}$, respectively. Sequence similarities to all other taxa included in the phylogenetic analysis were $<90.5 \%$ (Fig. 1). DNADNA hybridization was performed to determine genotypic relatedness between strain TF- $17^{\mathrm{T}}$ and the type strains of the three Microbulbifer species. Strain TF- $17^{\mathrm{T}}$ exhibited DNA-DNA relatedness levels of $11 \cdot 5,10 \cdot 0$ and $13.0 \%$ to M. hydrolyticus DSM $11525^{\mathrm{T}}$, M. salipaludis KCCM $41586^{\mathrm{T}}$ and M. elongatus DSM $6810^{\mathrm{T}}$, respectively.

The results of 16S rDNA sequence analysis revealed that strain $\mathrm{TF}-17^{\mathrm{T}}$ has the closest phylogenetic affiliation to the genus Microbulbifer, confirmed by a high bootstrap resampling value. Colonies of strain $\mathrm{TF}-17^{\mathrm{T}}$ are similar to those of $M$. elongatus in colour, whereas they are distinguishable from colonies of $M$. hydrolyticus and $M$. salipaludis in colour. The results obtained in chemotaxonomic analyses are most similar to the chemotaxonomic properties that are characteristic of the genus Microbulbifer (Yoon et al., 2003a, b). In particular, the predominant respiratory lipoquinone type and cellular fatty acid profile are useful for distinguishing strain TF- $17^{\mathrm{T}}$ and other members of the genus Microbulbifer from some other related genera. Strain TF- $17^{\mathrm{T}}$ and other members of the genus Microbulbifer contain Q-8 as the predominant respiratory lipoquinone (Yoon et al., 2003a, b), whereas members of the genus Marinobacter and authentic pseudomonads have been known to contain Q-9 as the predominant respiratory lipoquinone (Oyaizu \& Komagata, 1983; Yumoto et al., 2001; Yoon et al., 2003a). Strain TF- $17^{\mathrm{T}}$ can be distinguished from members of the genus Alcanivorax by cellular fatty acid profiles: strain TF- $17^{\mathrm{T}}$ and other members of the genus Microbulbifer contain iso- $\mathrm{C}_{15: 0}$ as the major fatty 
Table 2. Percentage cellular fatty acid composition of strain TF- $17^{\top}$, M. hydrolyticus DSM $11525^{\top}$, M. salipaludis KCCM $41586^{\top}$ and $M$. elongatus DSM $6810^{\top}$

Taxa: 1, strain TF- $17^{\mathrm{T}}$; 2, M. hydrolyticus DSM $11525^{\mathrm{T}}$; 3, M. salipaludis KCCM $41586^{\mathrm{T}}$; 4, M. elongatus DSM $6810^{\mathrm{T}}$. -, Not detected.

\begin{tabular}{|c|c|c|c|c|}
\hline Fatty acid ${ }^{\star}$ & 1 & 2 & 3 & 4 \\
\hline \multicolumn{5}{|l|}{ Straight-chain: } \\
\hline $\mathrm{C}_{10: 0}$ & $1 \cdot 3$ & $1 \cdot 7$ & $2 \cdot 4$ & $1 \cdot 6$ \\
\hline $\mathrm{C}_{14: 0}$ & $1 \cdot 0$ & $1 \cdot 2$ & $2 \cdot 6$ & $0 \cdot 7$ \\
\hline $\mathrm{C}_{15: 0}$ & $1 \cdot 6$ & $1 \cdot 5$ & $1 \cdot 7$ & $0 \cdot 9$ \\
\hline $\mathrm{C}_{16: 0}$ & $8 \cdot 7$ & $11 \cdot 4$ & $16 \cdot 3$ & $7 \cdot 1$ \\
\hline $\mathrm{C}_{17: 0}$ & $1 \cdot 3$ & $2 \cdot 9$ & $2 \cdot 2$ & $2 \cdot 5$ \\
\hline $\mathrm{C}_{17: 0}$ cyclo & $2 \cdot 3$ & $5 \cdot 7$ & - & - \\
\hline $\mathrm{C}_{18: 0}$ & - & $1 \cdot 6$ & $1 \cdot 4$ & $1 \cdot 2$ \\
\hline $\mathrm{C}_{19: 0} \omega 8 c$ cyclo & $1 \cdot 4$ & $1 \cdot 0$ & - & - \\
\hline \multicolumn{5}{|l|}{ Branched: } \\
\hline iso- $\mathrm{C}_{11: 0}$ & $10 \cdot 0$ & $5 \cdot 7$ & $4 \cdot 8$ & $6 \cdot 5$ \\
\hline iso- $\mathrm{C}_{15: 0}$ & $25 \cdot 9$ & $24 \cdot 4$ & $19 \cdot 4$ & $20 \cdot 7$ \\
\hline iso- $\mathrm{C}_{15: 1} \mathrm{~F} \dagger$ & $0 \cdot 8$ & $1 \cdot 0$ & $0 \cdot 7$ & $1 \cdot 0$ \\
\hline iso- $\mathrm{C}_{16: 0}$ & - & - & - & $0 \cdot 5$ \\
\hline iso- $\mathrm{C}_{17: 0}$ & $6 \cdot 9$ & $10 \cdot 4$ & $5 \cdot 5$ & $9 \cdot 9$ \\
\hline anteiso- $\mathrm{C}_{17: 0}$ & - & - & - & $0 \cdot 8$ \\
\hline iso- $\mathrm{C}_{17: 1} \omega 9 c$ & $12 \cdot 6$ & $10 \cdot 1$ & $9 \cdot 5$ & $11 \cdot 3$ \\
\hline \multicolumn{5}{|l|}{ Unsaturated: } \\
\hline $\mathrm{C}_{17: 1} \omega 8 c$ & - & $0 \cdot 5$ & $1 \cdot 0$ & $1 \cdot 8$ \\
\hline $\mathrm{C}_{18: 1} \omega 5 c$ & - & - & $0 \cdot 7$ & - \\
\hline $\mathrm{C}_{18: 1} \omega 7 c$ & $5 \cdot 6$ & $8 \cdot 9$ & $11 \cdot 8$ & $16 \cdot 3$ \\
\hline \multicolumn{5}{|l|}{ Hydroxy: } \\
\hline $\mathrm{C}_{10: 0} 3-\mathrm{OH}$ & $1 \cdot 7$ & $1 \cdot 0$ & $1 \cdot 2$ & $1 \cdot 6$ \\
\hline $\mathrm{C}_{16: 0} 2-\mathrm{OH}$ & - & - & $0 \cdot 9$ & - \\
\hline iso- $\mathrm{C}_{11: 0} 3-\mathrm{OH}$ & $14 \cdot 2$ & $6 \cdot 2$ & $5 \cdot 7$ & $7 \cdot 7$ \\
\hline iso- $\mathrm{C}_{17: 0} 3-\mathrm{OH}$ & - & - & $0 \cdot 9$ & - \\
\hline \multicolumn{5}{|l|}{ Summed feature: $\ddagger$} \\
\hline 3 & $2 \cdot 2$ & $2 \cdot 7$ & $7 \cdot 1$ & $6 \cdot 0$ \\
\hline 4 & - & - & $1 \cdot 7$ & - \\
\hline
\end{tabular}

${ }^{\star}$ Fatty acids that represented $<0.5 \%$ in all strains are omitted. $\dagger$ The double-bond position indicated by a capital letter is unknown. $¥$ Summed features represent groups of two or three fatty acids that could not be separated by GLC with the MIDI system. Summed feature 3 contained one or more of the following fatty acids: iso$\mathrm{C}_{15: 0} 2-\mathrm{OH}$ and/or $\mathrm{C}_{16: 1} \omega 7 c$. Summed feature 4 contained one or more of the following fatty acids: anteiso- $\mathrm{C}_{17: 1} \mathrm{~B}$ and/or iso- $\mathrm{C}_{17: 1} \mathrm{I}$.

acid, whereas members of the genus Alcanivorax contain $\mathrm{C}_{18: 1} \omega 7 c$ and $\mathrm{C}_{16: 0}$ as the major fatty acids (FernándezMartínez et al., 2003). Therefore, both phylogenetic and chemotaxonomic results indicate clearly that strain TF- $17^{\mathrm{T}}$ belongs to the genus Microbulbifer.

Although strain $\mathrm{TF}-17^{\mathrm{T}}$ is similar to M. elongatus in its morphological properties, it is differentiated from $M$. elongatus in some physiological properties (Table 1). There are some noteworthy differences between strain $\mathrm{TF}-17^{\mathrm{T}}$ and the other two Microbulbifer species in morphological, physiological and biochemical properties, including colour of colonies, maximum growth temperature, ability to hydrolyse some substrates and acid production from carbohydrates (Table 1). Levels of 16S rDNA similarity between strain $\mathrm{TF}-17^{\mathrm{T}}$ and the type strains of Microbulbifer species $(95 \cdot 1-95 \cdot 7 \%)$ are low enough to exclude the possibility of assigning strain $\mathrm{TF}-17^{\mathrm{T}}$ to a previously described Microbulbifer species (Stackebrandt \& Goebel, 1994). In addition, DNA-DNA relatedness levels justify that strain TF- $17^{\mathrm{T}}$ is separate from the three Microbulbifer species with validly published names (Wayne et al., 1987). Therefore, on the basis of phenotypic, chemotaxonomic and phylogenetic data and genotypic distinctiveness, strain TF- $17^{\mathrm{T}}$ should be placed in the genus Microbulbifer as the type strain of a novel species, for which we propose the name Microbulbifer maritimus sp. nov.

\section{Description of Microbulbifer maritimus sp. nov.}

Microbulbifer maritimus (ma.ri.ti'mus. L. masc. adj. maritimus living near the sea).

Cells are rods, $0 \cdot 3-0 \cdot 5 \mu \mathrm{m}$ wide and $3 \cdot 0-6 \cdot 0 \mu \mathrm{m}$ long. Gram-negative. Colonies on MA are yellowish-brown in colour, smooth, irregular, slightly raised and $2 \cdot 0-4 \cdot 0 \mathrm{~mm}$ in diameter after 3 days incubation at $37^{\circ} \mathrm{C}$. Optimal growth temperature is $37^{\circ} \mathrm{C}$. Growth occurs at 15 and $48{ }^{\circ} \mathrm{C}$, but not at $10^{\circ} \mathrm{C}$ or above $49^{\circ} \mathrm{C}$. Optimal growth $\mathrm{pH}$ is $6 \cdot 5-7 \cdot 5$. Growth occurs weakly at $\mathrm{pH} 5 \cdot 0$, but not at $\mathrm{pH} 4 \cdot 5$. Optimal growth occurs in the presence of $2-4 \%$ $\mathrm{NaCl}$. Growth occurs in the presence of $10 \% \mathrm{NaCl}$, but not without $\mathrm{NaCl}$ or in the presence of $>11 \% \mathrm{NaCl}$. No growth occurs under anaerobic conditions on MA. Predominant respiratory lipoquinone is Q-8. Major fatty acid is iso- $\mathrm{C}_{15: 0}$ and significant amounts of iso- $\mathrm{C}_{11: 0}$ $3-\mathrm{OH}$ and iso- $\mathrm{C}_{17: 1} \omega 9 \mathrm{c}$ are also present. DNA $\mathrm{G}+\mathrm{C}$ content is $59.9 \mathrm{~mol} \%$ (determined by HPLC). Tyrosine is hydrolysed, but hypoxanthine, xanthine and xylan are not. Acid is not produced from adonitol, myo-inositol, Dmannitol, D-melezitose, melibiose, D-raffinose, L-rhamnose, D-ribose, D-sorbitol or stachyose. D-Glucose, D-cellobiose, L-arginine, L-serine, acetate, butyrate, DL-malate, pyruvate and succinate are utilized for growth. D-Fructose, lactose, mannose, sucrose, hexadecane, mannitol, ethanol, methanol, benzoate, citrate, formate, DL-glutamate and lactate are not utilized. The following enzymes are present when assayed with the API ZYM system: alkaline phosphatase, esterase (C4), lipase (C8), leucine arylamidase, acid phosphatase and naphthol-AS-BI-phosphohydrolase. The following enzymes are absent when assayed with the API ZYM system: lipase (C14), valine arylamidase, cystine arylamidase, trypsin, $\alpha$-chymotrypsin, $\alpha$-galactosidase, $\beta$ galactosidase, $\beta$-glucuronidase, $\alpha$-glucosidase, $\beta$-glucosidase, $N$-acetyl- $\beta$-glucosaminidase, $\alpha$-mannosidase and $\alpha$-fucosidase. Other phenotypic properties are given in Table 1.

The type strain is TF $-17^{\mathrm{T}}\left(=\mathrm{KCCM} 41774^{\mathrm{T}}=\mathrm{JCM} 12187^{\mathrm{T}}\right)$, which was isolated from an intertidal sediment from the Yellow Sea, Korea. 


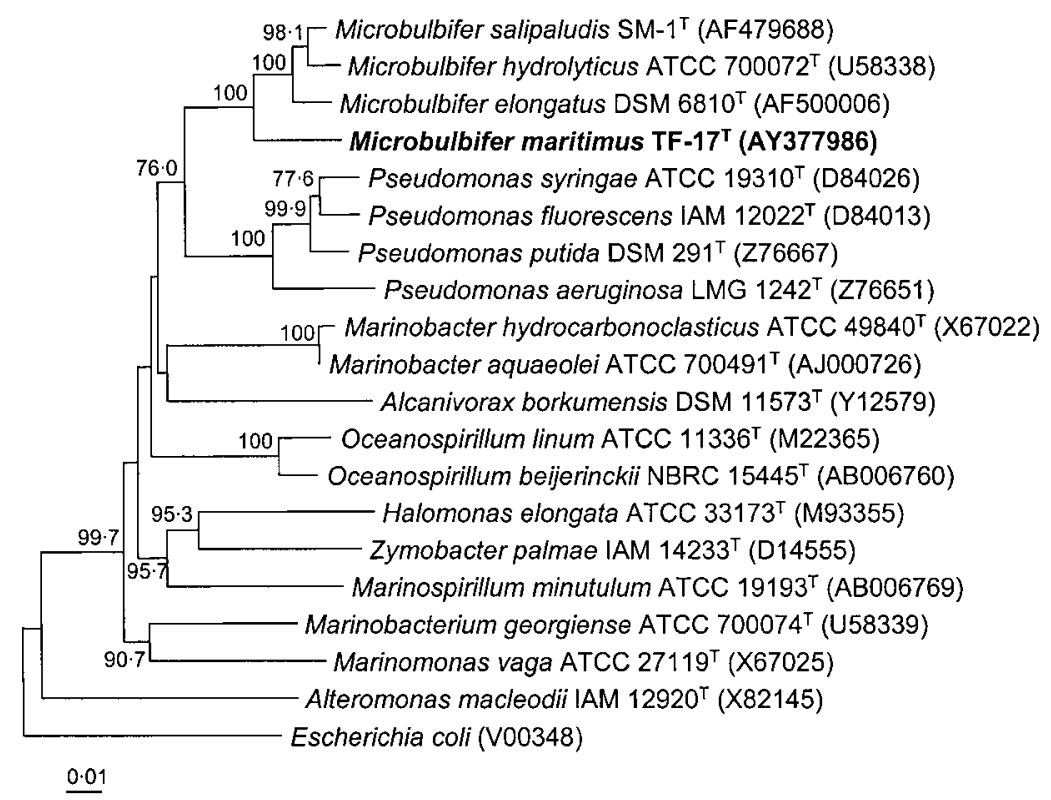

Fig. 1. Neighbour-joining tree showing the phylogenetic positions of strain TF- $17^{\top}$ and representatives of the $\gamma$-subclass of the Proteobacteria, based on 165 rDNA sequences. Bootstrap values (expressed as percentages of 1000 replications) $>50 \%$ are shown at branch-points. Bar, 0.01 substitutions per nucleotide position.

\section{Acknowledgements}

This work was supported by the 21C Frontier program of Microbial Genomics and Applications (grant MG02-0401-001-1-0-0) and NRL research programme (grant M10104000294-01J0 00012811) from the Ministry of Science and Technology (MOST) of the Republic of Korea.

\section{References}

Anzai, Y., Kim, H., Park, J.-Y., Wakabayashi, H. \& Oyaizu, H. (2000). Phylogenetic affiliation of the pseudomonads based on 16S rRNA sequence. Int J Syst Evol Microbiol 50, 1563-1589.

Baumann, P. \& Baumann, L. (1981). The marine Gram-negative eubacteria: genera Photobacterium, Beneckea, Alteromonas, Pseudomonas, and Alcaligenes. In The Prokaryotes, pp. 1302-1331. Edited by M. P. Starr, H. Stolp, H. G. Trüper, A. Balows \& H. G. Schlegel. Berlin: Springer.

Cowan, S. T. \& Steel, K. J. (1965). Manual for the Identification of Medical Bacteria. London: Cambridge University Press.

Ezaki, T., Hashimoto, Y. \& Yabuuchi, E. (1989). Fluorometric deoxyribonucleic acid-deoxyribonucleic acid hybridization in microdilution wells as an alternative to membrane filter hybridization in which radioisotopes are used to determine genetic relatedness among bacterial strains. Int J Syst Bacteriol 39, 224-229.

Felsenstein, J. (1981). Evolutionary trees from DNA sequences: a maximum likelihood approach. J Mol Evol 17, 368-376.

Felsenstein, J. (1993). PHYLIP (phylogeny inference package), version 3.5c. Department of Genetics, University of Washington, Seattle, USA.

Fernández-Martínez, J., Pujalte, M. J., Garcia-Martínez, J., Mata, M., Garay, E. \& Rodríguez-Valera, F. (2003). Description of Alcanivorax venustensis sp. nov. and reclassification of Fundibacter jadensis DSM $12178^{\mathrm{T}}$ (Bruns and Berthe-Corti 1999) as Alcanivorax jadensis comb. nov., members of the emended genus Alcanivorax. Int J Syst Evol Microbiol 53, 331-338.

González, J. M., Mayer, F., Moran, M. A., Hodson, R. E. \& Whitman, W. B. (1997). Microbulbifer hydrolyticus gen. nov., sp. nov., and Marinobacterium georgiense gen. nov., sp. nov., two marine bacteria from a lignin-rich pulp mill waste enrichment community. Int J Syst Bacteriol 47, 369-376.
Humm, H. J. (1946). Marine agar-digesting bacteria of the South Atlantic coast. Bull Duke Univ Mar Sta 3, 45-75.

Jukes, T. H. \& Cantor, C. R. (1969). Evolution of protein molecules. In Mammalian Protein Metabolism, pp. 21-132. Edited by H. N. Munro. New York: Academic Press.

Kluge, A. G. \& Farris, F. S. (1969). Quantitative phyletics and the evolution of anurans. Syst Zool 18, 1-32.

Komagata, K. \& Suzuki, K. (1987). Lipid and cell wall analysis in bacterial systematics. Methods Microbiol 19, 161-206.

Lanyi, B. (1987). Classical and rapid identification methods for medically important bacteria. Methods Microbiol 19, 1-67.

Leifson, E. (1963). Determination of carbohydrate metabolism of marine bacteria. J Bacteriol 85, 1183-1184.

Levring, T. (1946). Some culture experiments with Ulva and artificial seawater. Kungl Fysiografiska Sällsk Lund Förhandlingar 16, 45-56.

Oyaizu, H. \& Komagata, K. (1983). Grouping of Pseudomonas species on the basis of cellular fatty acid composition and the quinone system with special reference to the existence of 3-hydroxy fatty acids. J Gen Appl Microbiol 29, 17-40.

Palleroni, N. J. (1984). Genus Pseudomonas Migula 1894. In Bergey's Manual of Systematic Bacteriology, vol. 1, pp. 141-199. Edited by N. R. Krieg \& J. G. Holt. Baltimore: Williams \& Wilkins.

Saitou, N. \& Nei, M. (1987). The neighbor-joining method: a new method for reconstructing phylogenetic trees. Mol Biol Evol 4, 406-425.

Solano, F. \& Sanchez-Amat, A. (1999). Studies on the phylogenetic relationships of melanogenic marine bacteria: proposal of Marinomonas mediterranea sp. nov. Int J Syst Bacteriol 49, 1241-1246.

Stackebrandt, E. \& Goebel, B. M. (1994). Taxonomic note: a place for DNA-DNA reassociation and 16S rRNA sequence analysis in the present species definition in bacteriology. Int J Syst Bacteriol 44, 846-849.

Tamaoka, J. \& Komagata, K. (1984). Determination of DNA base composition by reverse-phase high-performance liquid chromatography. FEMS Microbiol Lett 25, 125-128.

Thompson, J. D., Higgins, D. G. \& Gibson, T. J. (1994). CLUSTAL W: improving the sensitivity of progressive multiple sequence alignment 
through sequence weighting, position-specific gap penalties and weight matrix choice. Nucleic Acids Res 22, 4673-4680.

Wayne, L. G., Brenner, D. J., Colwell, R. R. \& 9 other authors (1987). International Committee on Systematic Bacteriology. Report of the ad hoc committee on reconciliation of approaches to bacterial systematics. Int J Syst Bacteriol 37, 463-464.

Yoon, J.-H., Kim, H., Kim, S.-B., Kim, H.-J., Kim, W. Y., Lee, S. T., Goodfellow, M. \& Park, Y.-H. (1996). Identification of Saccharomonospora strains by the use of genomic DNA fragments and rRNA gene probes. Int J Syst Bacteriol 46, 502-505.

Yoon, J.-H., Lee, S. T. \& Park, Y.-H. (1998). Inter- and intraspecific phylogenetic analysis of the genus Nocardioides and related taxa based on $16 \mathrm{~S}$ rDNA sequences. Int J Syst Bacteriol 48, 187-194.

Yoon, J.-H., Kim, H., Kang, K. H., Oh, T.-K. \& Park, Y.-H. (2003a). Transfer of Pseudomonas elongata Humm 1946 to the genus
Microbulbifer as Microbulbifer elongatus comb. nov. Int J Syst Evol Microbiol 53, 1357-1361.

Yoon, J.-H., Kim, I.-G., Shin, D.-Y., Kang, K. H. \& Park, Y.-H. (2003b). Microbulbifer salipaludis sp. nov., a moderate halophile isolated from a Korean salt marsh. Int J Syst Evol Microbiol 53, 53-57.

Yumoto, I., Yamazaki, K., Hishinuma, M., Nodasaka, Y., Suemori, A., Nakajima, K., Inoue, N. \& Kawasaki, K. (2001). Pseudomonas alcaliphila sp. nov., a novel facultatively psychrophilic alkaliphile isolated from seawater. Int J Syst Evol Microbiol 51, 349-355.

Yurkov, V., Stackebrandt, E., Holmes, A. \& 7 other authors (1994). Phylogenetic positions of novel aerobic, bacteriochlorophyll $a$ containing bacteria and description of Roseococcus thiosulfatophilus gen. nov., sp. nov., Erythromicrobium ramosum gen. nov., sp. nov., and Erythrobacter litoralis sp. nov. Int J Syst Bacteriol 44, 427-434. 